\title{
粒状体の流動則における 応力増分依存性に関する微視力学的研究
}

\author{
A Micromechanical Study on the Dependency of Incremental Stress \\ on the Flow Rule of Grnular Media
}

\author{
金子賢治*，岸野佑次** \\ Kenji KANEKO and Yuji KISHINO
}

\begin{abstract}
*正会員 工博 東北大学大学助手 大学院工学研究科土木工学専攻（ T980-8579 仙台市青葉区荒巻字青葉） **正会員 工博 東北大学教授 大学院工学研究科土木工学専攻（同 上）
\end{abstract}

\begin{abstract}
Observing numerical results obtained by Granular Element Method, we discuss the incremental stress-strain behavior of granular materials. We assume a periodic boundary for the numerical experiments to avoid disturbances caused by boundary controlling. Stress-probe tests starting with the intermediate data of a bi-axial compression test give a set of incremental stress-strain relationships. The result indicates that the flow direction for plastic loading is not constant as is assumed in the classical plasticity theory and depends on the direction of the stress increment. Comparing the numerical results with a proposed flow rule, we conclude that the origin of the direction dependency is the volumetric component of plastic strain.
\end{abstract}

Key Words: dependency of incremental stress, flow rule, granular media, periodic boundary, GEM

\section{1.はじめに}

流動則の応力増分方向依存性は, 局所化や分岐の 解析をはじめとして地盤材料のような粒状材料の 種々の力学問題に対して非常に重要な性質であるこ とが認識されつつある。「応力増分方向依存性」と は, 応力増分の方向によって塑性流動方向が変化す る変形特性を指し，増分非線形性等と呼ばれる場合 もある．粒状体のこのような性質は古典的な金属塑 性論流動則では表現し得ない変形特性である。

流動則の応力増分方向依存性を表現できる構成モ デルとして, Hypoplasticiy ${ }^{1), 2)}$ や $J_{2}$ 変形理論 ${ }^{3)}$, 接線 塑性 ${ }^{4)}$ 等が提案されている。これらのモデルは, 粒 子集合体を連続体と見なして現象論的にその変形特 性をモデル化したもので，これらのモデルを統一的 に解釈するためには，応力増分方向依存性が生じる 理由, 金属等の他の材料との違い, 依存性の程度等 を知ることが重要となる。

このような流動則に関する問題に対しての各種情 報を収集するために，Anandarajahら ${ }^{5)}$ はオタワ砂を 用いて応力プローブ実験を行い，Failur Lineに近い 応力状態においては一般的な金属塑性論が十分適用 できると結論り゙けている。また，Royisら゙は応力増 分方向に対する全ひずみ増分応答を砂の応力プロー ブ実験により調べ, Hypoplasticiyの検証を行った.

しかしながら，実実験による応力プローブ試験は非 常に困難であり, 応力増分方向の数も少なく, 各応 力増分方向に対するそれぞれ違う供試体を用いるこ
とによる挙動のばらつき等もあるため精密なデー夕 が得られているとは言い切れない。 また，実材料を 用いた室内要素試験は微視的観点からの考察は不可 能に近く応力増分方向依存性の発生メカニズムを捉 えることはできない。一方, 武ら ${ }^{7-9)}$ は, 境界粒子を 用いて円形領域内の粒子集合体を制御して行った 2 次元粒状要素法 (GEM) による応力プローブ試験 シミュレーションにより，粒状体の流動則はほぼ非 関連型に近いが厳密には応力増分方向に依存するこ と等の流動則に関する一連の結論を導いている。

本研究では，理想的な境界制御により材料本来の 力学特性を抽出できる周期境界制御 $\mathrm{GEM}^{10)}$ を用いて 応力プローブ試験シミュレーションを行い, 武らの 結論を再確認すると共に, 塑性ひずみ増分の応力増 分方向依存性に着目して粒状体の流動則に関して考 察する. 特に, 巨視的に流動則の応力増分方向依存 性として現れる原因となる微視的現象，応力増分方 向依存性を表現しうる拡張流動則を中心に議論す る。

ところで，著者らが提案した数学的均質化理論に

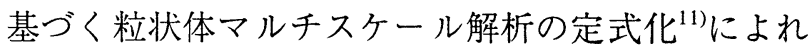
ば，周期的微視構造が巨視的全体構造に対する材料 の構成関係を与えると解䣋される。ここで用いる周 期境界制御GEMは，マルチスケール解析において 構成関係を与える微視問題の解法そのものであり, 本研究は微視問題に着目した多数の数值実験により 粒状体の巨視的な構成モデルに関する種々の情報を 収集・考察するための一連の研究の一部である。 


\section{2. 周期境界制御粒状要素法の概要}

粒状体の離散体モデルに基づく数值シミュレー ション方法としてCundallらによって提案された個別 要素法（DEM） ${ }^{12)}$ が有名で，これを応用した多くの 数值解析的研究が行われている ${ }^{13)-15)}$. DEMは粒状体 を構成する粒子の動的な運動方程式に基づく数值シ ミュレーション手法である．粒子間接触力は粒子の 弾性的性質を反映して与えられるが，通常，粒子を 剛体と仮定し粒子間接触点に仮想バネ要素を配する ことで接触粒子間には互いに重なることを許し，接 触力は重なり量に比例して生じると仮定される.

一方， $\mathrm{GEM}^{16}{ }^{16}$ は剛体粒子や粒子間仮想バネ要素な どを用いる粒子間の構成関係に関してはDEMとほ ぼ同様である。両者の主な相違点は，DEMが個々 の粒子の運動方程式に基づいて差分法により粒子の 運動を追跡するのに対して, GEMは全体剛性マト リックスに基づいてつり合い条件を満足しながら増 分計算を行う点である.GEMがより精度の高い境 界制御を可能とし，より精密に粒状体の準静的な力 学特性を抽出可能であることが示されている7-9). 本 研究では, 周期境界制御による $\mathrm{GEM}^{10), 11}$ を用いて解 析を行うこととし，以下，その概要をマトリックス 表記で示す。

\section{1 周期境界条件と応力, ひずみの定義}

解析対象とする基本単位構造の周期性を仮定した 周期境界の概念を図-1に示す。ここでは，図-1に示 すように, 粒子 $P$ に相当する隣接領域の粒子を粒子 $P$ のダミ一粒子 $D$ と称することとする．粒子 $P$ の位 置ベクトルを $\boldsymbol{x}^{P}$, ダミ一粒子の位置ベクトルを $\boldsymbol{x}^{D}$ として，粒子 $P$ およびダミ一粒子 $D$ の変位増分ベク トルは平均ひずみ増分 $\Delta \varepsilon$ を用いて次式のように分 解することができる。

$$
\begin{aligned}
& \Delta \boldsymbol{U}^{P}=\Delta \boldsymbol{U}^{P^{0}}+\Delta \boldsymbol{U}^{P^{1}}=\Delta \boldsymbol{\varepsilon} \boldsymbol{x}^{P}+\Delta \boldsymbol{U}^{P^{1}} \\
& \Delta \boldsymbol{U}^{D}=\Delta \boldsymbol{U}^{D^{0}}+\Delta \boldsymbol{U}^{D^{1}}=\Delta \boldsymbol{\varepsilon} \boldsymbol{x}^{D}+\Delta \boldsymbol{U}^{D^{1}}
\end{aligned}
$$

ここで， $\Delta U^{P^{1}} ， \Delta U^{D^{1}}$ は粒子 $P$ およびダミー粒子 $D$ の微視変位増分べクトルと呼ばれる，微視変位増分 ベクトルは粒子の変位増分ベクトルから基本単位構 造全体の平均的な变位増分 $\Delta U^{0}=\Delta \boldsymbol{\varepsilon} \boldsymbol{x}$ を除いた部分 であり，各粒子の非均質な変位を表す．周期境界条 件は，この微視変位増分ベクトルを用いて次式で与 えられる ${ }^{11}$.

$$
\Delta U^{P^{1}}=\Delta U^{D^{1}}
$$

基本単位構造の形状を特徵づける周期形状べクト $ル \boldsymbol{L}^{h}=\left\{L_{1}^{h}, L_{2}^{h}\right\}^{\mathrm{T}}, \quad \boldsymbol{L}^{v}=\left\{L_{1}^{v}, L_{2}^{v}\right\}^{\mathrm{T}}$ を図-1のように導入 する。周期べクトル $\boldsymbol{L}^{h}, \boldsymbol{L}^{\nu}$ の各成分を用いて平均 ひずみテンソル $\boldsymbol{\varepsilon}$ は次式で定義される。

$$
\boldsymbol{\varepsilon}=\left[\begin{array}{cc}
\frac{L_{1}^{h}}{L_{1}^{h^{0}}}-1 & \frac{1}{2}\left(\frac{L_{2}^{h}}{L_{1}^{h^{0}}}+\frac{L_{1}^{v}}{L_{2}^{v 0}}\right) \\
\frac{1}{2}\left(\frac{L_{2}^{h}}{L_{1}^{h^{0}}}+\frac{L_{1}^{v}}{L_{2}^{v 0}}\right) & \frac{L_{1}^{v}}{L_{1}^{v^{0}}}-1
\end{array}\right]
$$

ここに，上付文字 0 は初期状態の值を表す.

GEMにおいて粒状集合体の平均応力は, 仮想仕 事の原理に従って与えられる ${ }^{16)}$. 同様の考え方で, 周期境界制御GEMにおける 基本単位構造の平均ひ ずみ $\boldsymbol{\varepsilon}$ に対応する平均応力 $\sigma$ を次式で定義する.

$$
\boldsymbol{\sigma} \equiv \frac{1}{V} \sum_{C D} f^{C D} x^{C D}
$$

ここに, $f C D$ はダミ一粒子から基本単位構造内部の 粒子に作用する接触力べクトル， $x^{C D}$ は基本単位構 造内部の粒子とダミー粒子との接触点の位置ベクト ル，Vは基本単位構造の体積である（図-2）。ま た， $\Sigma_{C D}$ は基本単位構造内部の粒子とダミー粒子と の全接触点についての総和を意味する，GEMにお いては, 全粒子のモーメントのつり合い条件を満た すため, 式(4)で与えられる平均応力は対称となる.

\section{2 粒子間の構成式}

図-3に示す概念図を基に GEM で用いる粒子間接 触点の構成式について概説する。接触力ベクトル $f^{C}=\left(f_{n}^{C}, f_{t}^{C}\right)^{\mathrm{T}}$ に対応する運動学的変数は相対変位

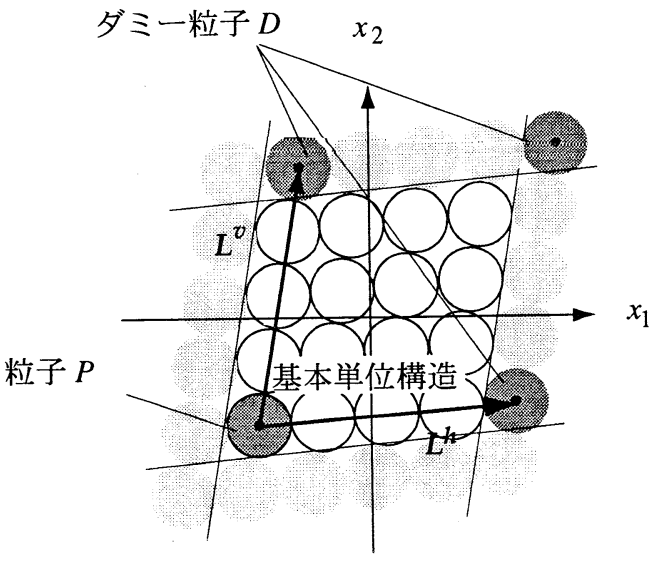

図-1 周期境界の概念

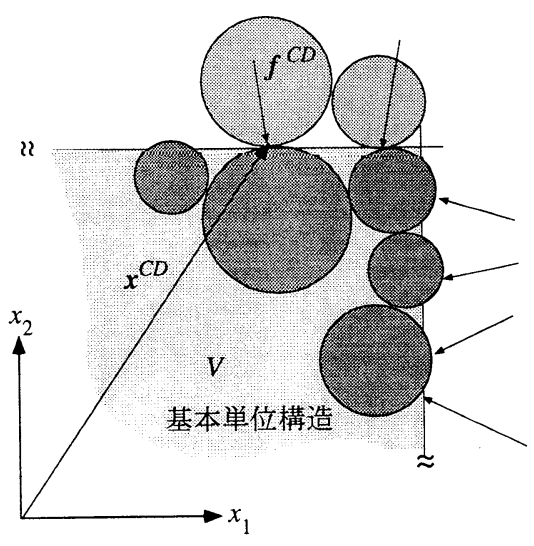

図-2 ダミー粒子が作用する接触力 
ベクトル $\boldsymbol{u}^{C}=\left(u_{n}^{C}, u_{t}^{C}\right)^{\mathrm{T}}$ であり，これらは $\left(\boldsymbol{n}^{C}, \boldsymbol{t}^{C}\right)$ を 基底べクトルとする接触点における局所座標系で定 義される。ここに， $\boldsymbol{n}^{C}$ は接触点における外向き単 位法線ベクトル， $t^{C}$ は図-3(a)のように反時計回り を正とした単位接線べクトルであり， $t_{1}^{C}=-n_{2}^{C}$, $t_{2}^{C}=n_{1}^{C}$ が成り立つ。一方, 全体座標系で定義され る粒子 $a$ 重心の変位・回転べクトルを回転量 $\omega^{a}$ とし

$$
\boldsymbol{U}^{a}=\left(U_{1}^{a}, U_{2}^{a}, r^{a} \omega^{a}\right)^{\mathrm{T}}
$$

と定義する.

相対変位増分ベクトル $\Delta u^{C}$ と粒子 $a, b$ の変位増 分ベクトル $\Delta \boldsymbol{U}^{a}, \Delta \boldsymbol{U}^{b}$ とは座標変換マトリックス $T^{C} ， T^{\prime C}$ を用いて次式により関係づけられる。

$$
\begin{aligned}
\Delta \boldsymbol{u}^{C} & =\boldsymbol{T}^{C} \Delta \boldsymbol{U}^{a}-\boldsymbol{T}^{\prime C} \Delta \boldsymbol{U}^{b} \\
\boldsymbol{T}^{C} & =\left[\begin{array}{ccc}
n_{1}^{C} & n_{2}^{C} & 0 \\
-n_{2}^{C} & n_{1}^{C} & 1
\end{array}\right], \quad \boldsymbol{T}^{\prime C}=\left[\begin{array}{ccc}
n_{1}^{C} & n_{2}^{C} & 0 \\
-n_{2}^{C} & n_{1}^{C} & -1
\end{array}\right]
\end{aligned}
$$

粒状体を構成している粒子の弾性的な性質を, 粒 子間接触点において法線および接線方向に仮想バネ 要素を設けることにより考慮することとし，粒子自 身は剛体であるとする。

$$
\begin{aligned}
\Delta \boldsymbol{f}^{C} & =\boldsymbol{K} \Delta \boldsymbol{u}^{C} \\
\boldsymbol{K} & =\left[\begin{array}{cc}
k_{n} & 0 \\
0 & k_{t}
\end{array}\right]: \text { 仮想バネ剛性マトリックス }
\end{aligned}
$$

ここに， $k_{n}, k_{t}$ は接触点における法線および接線方

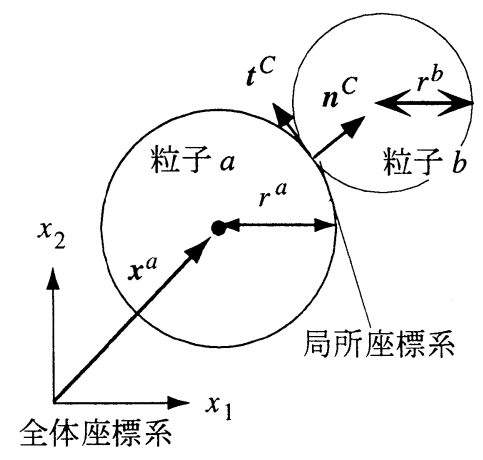

(a) 全体座標系と局所座標系

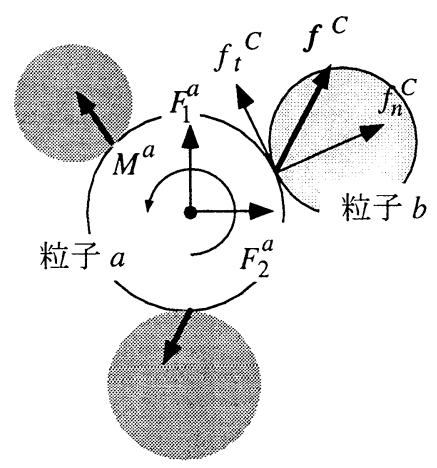

（b）接触力, 合力, モーメント

図-3 粒状要素法の概念
向のバネ定数である.

接触力の接線方向成分がMohr-Coulmbの摩擦則で 表される条件

$$
\left|f_{t}^{C}\right| \geq-f_{n}^{C} \tan \phi+c
$$

を満たす場合には次式のように強制的にこの限界值 に戻す修正を行う。

$$
f_{t}^{C^{\prime}}=\frac{f_{t}^{C}}{\left|f_{t}^{C}\right|}\left(-f_{n}^{C} \tan \phi+c\right)
$$

ここに, $\phi$ は粒子間摩擦角, $c$ は粒子間粘着力である.

粒子同士の接触条件は法線方向相対変位を用いて $u_{n}^{C}<0$

と表される，接触条件を満たさない場合には接触力 は法線方向, 接線方向ともに強制的に 0 とおく.

以上のように，粒子自身は弾性体と想定している が, 粒子間接触点における接触・摩擦により粒子の 運動が制約され，巨視的には非線形な材料応答とし て現れる。

\section{3 つり合い式の誘導 ${ }^{11)}$}

粒子 $a$ の静的つり合い条件式は,

$$
\boldsymbol{F}^{a}=\sum_{C} \boldsymbol{T}^{C^{\mathrm{T}}} \boldsymbol{f}^{C}=0
$$

と書くことができる。ここで， $\boldsymbol{F}^{a}$ は粒子に作用す る合力 $F_{1}^{a}, F_{2}^{a}$ とモーメント $M^{a}$ を並べたベクトル $\boldsymbol{F}^{a}=\left(F_{1}^{a}, F_{2}^{a}, M^{a} / r^{a}\right)^{\mathrm{T}}$ である（図-3）。

粒状体全体の静的つり合い条件式は，式(11)を全 粒子について重ね合わせた次式により与えられる。

$$
\boldsymbol{F}=\boldsymbol{T} \boldsymbol{f}=0
$$

ここに，Fは全粒子の重心に作用する力とモーメン トを並べたベクトル， $\boldsymbol{T}$ は各接触点の座標変換マト リックス $\boldsymbol{T}^{C}$ から構成される全体座標変換マトリッ クスである．全体座標変換マトリックス $\boldsymbol{T}$ は粒子の 運動に伴い時々刻々変化し, つり合い式(12)は非線 形方程式となる。

式(11)の個々の粒子のつり合い条件の増分形を線 形構成式(7), 相対変位増分一変位増分関係式(6)を 用いて書き直し次式を得る。

$$
\begin{gathered}
\sum_{C} \boldsymbol{T}^{C^{\mathrm{T}}} \Delta \boldsymbol{f}^{C}=\sum_{C} \boldsymbol{T}^{C^{\mathrm{T}}} \boldsymbol{K} \Delta \boldsymbol{u}^{C} \\
=\boldsymbol{S}^{e} \Delta \boldsymbol{U}^{a}-\sum_{C} \boldsymbol{S}^{\boldsymbol{e}^{\prime}} \Delta \boldsymbol{U}^{b}=0 \\
\text { ここで, } \\
\boldsymbol{S}^{e}=\sum_{C} \boldsymbol{T}^{C^{\mathrm{T}}} \boldsymbol{K} \boldsymbol{T}^{C}, \quad \boldsymbol{S}^{\boldsymbol{e}^{\prime}}=\boldsymbol{T}^{C^{\mathrm{T}} \boldsymbol{K} \boldsymbol{T}^{\prime} C}
\end{gathered}
$$

は要素剛性マトリックスである.

さらに，式(13)を全粒子について重ね合わけると 解くべき増分形つり合い式は次式で表される。

$S \Delta U=0$

$S$ は要素剛性マトリックスを全粒子について重ね合 わせた全体剛性マトリックスであり， $\Delta U$ は全粒子 の変位・回転べクトルを並べたべクトルである. 
GEMにおいては, 式(14)をある境界条件の下で解 くことにより解析を行うが，ここでは周期境界条件 (2)を考慮し，解くべき増分形つり合い式が次式のよ うに導出される ${ }^{11)}$.

$$
\Delta H=S \Delta U
$$

ここで， $\Delta \boldsymbol{H}$ は平均ひずみ増分 $\Delta \boldsymbol{\varepsilon}$ により隣接領域の 粒子が基本単位構造内部粒子に作用する外力項と見 なされる。

\section{3. 応カプローブ試験シミュレーション}

\section{1 解析の概要}

解析に用いた基本単位構造を図-4に示す。この基 本単位構造はほほ正方形領域内の 200 個の円形粒子 で構成され，粒径0.3-0.6mmの粒子がランダムに配 置されている。接触点の法線および接線方向のバネ 定数はそれぞれ $k_{n}=5.0 \times 10^{4} \mathrm{~N} / \mathrm{m}, k_{t}=3.5 \times 10^{4} \mathrm{~N} / \mathrm{m}$, 粒 子間摩擦角 $\phi=25^{\circ}$, 粒子間粘着力 $c=0$ とした.

各材料パラメー夕については武らの解析7-99 に倣っ て定めた。本研究の議論に関しては，ここで用いた 粒子数や材料パラメー夕の值等の基本単位構造の設 定によりその傾向がほとんど変化しないことが示さ

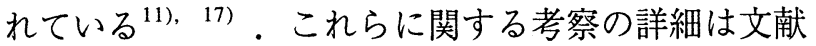
17)を参照されたい.

ここで行った解析の主応力空間上のせん断載荷経

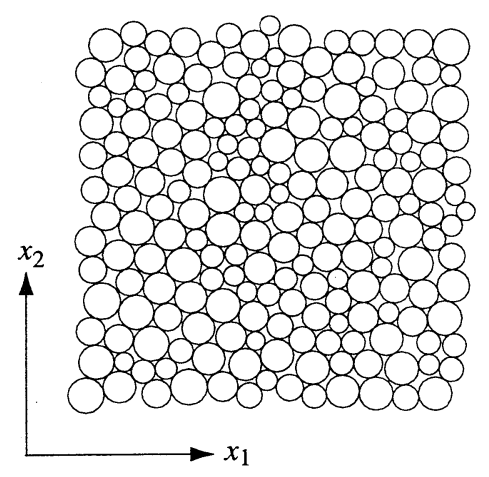

図-4 解析に用いた基本単位構造

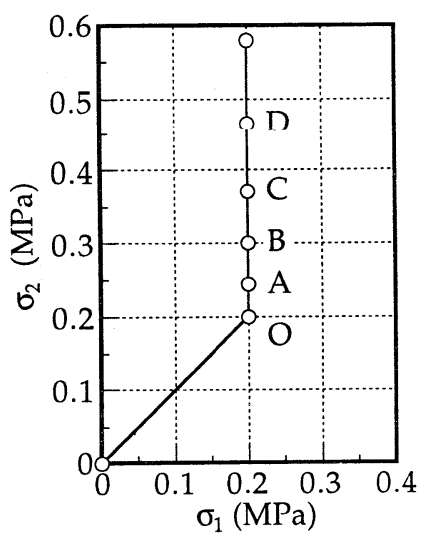

図-5 主応力空間上の載荷経路とプローブ試験点
路を図-5に示す．等方応力 $\sigma^{0}=0.2 \mathrm{MPa}$ の初期パッ キングを生成した後，応力制御によるせん断載荷を 行った．さらに，そこで得られたデー夕を基に図-5中 に示した 5 点 $(\mathrm{O}, \mathrm{A} \sim \mathrm{D})$ において応力プローブ試 験を行った。なお，ここでの解析においては，主応 力軸は常に $x_{1}, x_{2}$ 軸に一致する.

図-6にせん断載荷シミュレーション結果を示す。 図中の各パラメー夕は $\varepsilon_{1}, \varepsilon_{2}$ を主ひずみ， $\sigma_{1}, \sigma_{2}$ を主応力として次式で表される。

$$
\begin{aligned}
\gamma_{\max } & =\left|\varepsilon_{1}-\varepsilon_{2}\right| \times 100(\%) \\
\sigma_{r} & =q / p \\
& =\left(\sigma_{1}+\sigma_{2}\right) / 2, \quad q=\left|\sigma_{1}-\sigma_{2}\right| / 2 \\
\varepsilon_{v} & =-\left(\varepsilon_{11}+\varepsilon_{22}\right) \times 100(\%)
\end{aligned}
$$

側圧一定 2 軸圧縮経路で行ったシミュレーション結 果はダイレイタンシーが応力ピーク付近でも正（圧 縮）であり, 緩い砂の実験のような解析結果が得ら れている.

ここで用いたパッキングの他に数種類のパッキン グで解析を行ったが，周期境界制御GEMにおいて 側圧一定 2 軸圧縮経路のせん断シミュレーションで 応力のピーク付近のダイレイタンシーが膨張側にな るような密な砂とみなせる解析結果は得られていな い. 従来の粒状要素法においては正のダイレイタン シーが生じる解析結果 ${ }^{16),}{ }^{18)}$ も存在することから, 境 界制御によるものと考えられる。また， 2 次元解析 であることや初期パッキング生成過程の違いによる 影響とも考えられ，明確な結論には至っていない。 初期状態の密度や粒度分布などとも関連させて今後 明らかにするべき解析手法上の課題である.

図-5中に示したプローブ試験点は応力比 $0.1 ， 0.2$, 0.3，0.4のように応力比 $\sigma_{r}$ を基準として選定してい る. 図-6からわかるように試験点Oは初期等方応力 状態，A，Bはほほ弾性的な挙動を示す試験点，C, Dは塑性的な挙動は示しているが応力ピークよりは 手前の安定した硬化段階の試験点である.

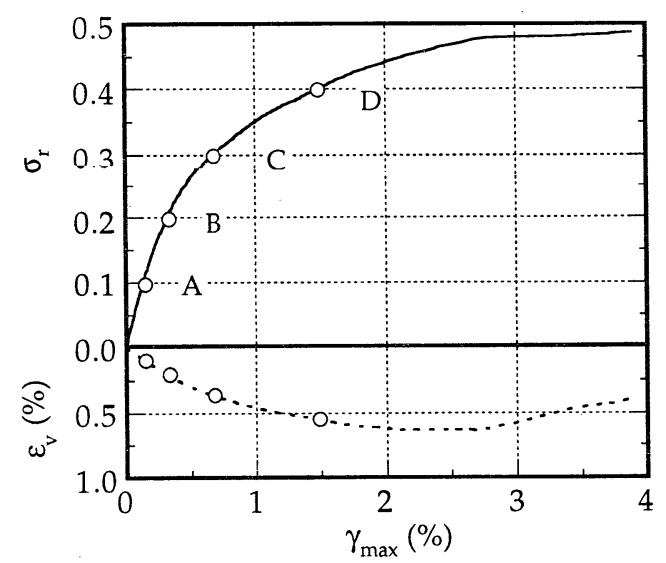

図-6 載荷曲線 


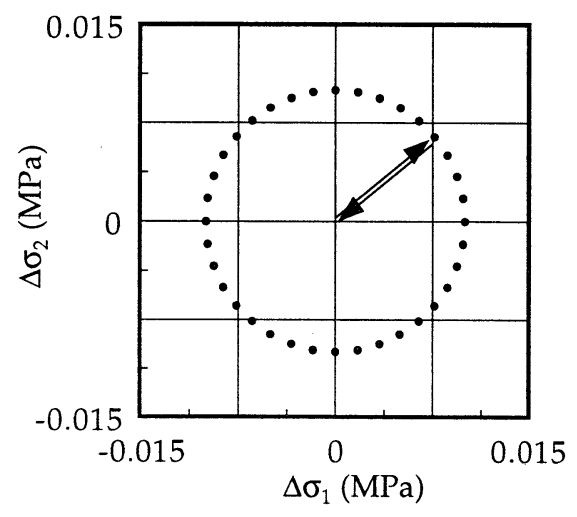

図-7 応力プローブ方向の主応力増分空間表示

5つのプローブ試験点において図-7の主応力増分 空間上に示す $10^{\circ}$ 毎合計 36 方向について応力増分の 大きさ $\sqrt{\Delta \sigma_{i j} \Delta \sigma_{i j}}=0.01(\mathrm{MPa})$ として載荷・除荷を行 い，弾性ひずみ増分と塑性ひずみ増分を算出する。 まず，載荷経路として $\Delta \sigma$ を基本単位構造に作用さ せ，応答として得られる平均ひずみ増分を $\Delta \boldsymbol{\varepsilon}^{l}$ とす る. 次に, 除荷経路として $-\Delta \sigma$ を作用させ，このと き得られるひずみ増分を $\Delta \varepsilon^{u}$ とすれば， $-\Delta \varepsilon^{u}$ が弾性 ひずみ増分 $\Delta \boldsymbol{\varepsilon}^{e}$ と見なされる。ささらに，塑性ひずみ 増分を $\Delta \boldsymbol{\varepsilon}^{p}=\Delta \boldsymbol{\varepsilon}^{l}-\Delta \boldsymbol{\varepsilon}^{e}$ として算出する。

\section{2 弾性増分応答}

図-8に試験点 $\mathrm{O}, \mathrm{B}, \mathrm{D}$ の弾性ひずみ増分を示す．同 図(a)には初期状態のプローブ試験結果を黒丸で，あ るプローブ方向の応力増分と弾性ひずみ増分より求 めたヤング率40MPa，ポアソン比0.157の等方弾性体 の弾性ひずみ増分を実線で示した。同図より，初期 状態の弾性ひずみ応答は等方弾性体の構成式で精度 良く近似できることがわかる。

載荷が進むと弾性ひずみ増分が示す楕円が除々に 傾き誘導異方性が観察される. 試験点Bのような塑性 変形がそれほど大きくない試験点においては楕円は 初期状態し比-゙て人きくは変化しないか，応力比 0.4 の試験点Dにおいては棈円の長軸方向は 1 軸方向に より近づき，楕円の形状も大きく崩れて初期状態に 比べて大きくなる。これは, ユニットセル内部の微視 構造が異方的に変化するためであると考えられる.

このような弾性応答を連続体構成則で表そうとす れば，損傷理論のように微視的内部構造の劣化に伴 い弾性マトリックスが変化するようなモデルが考え られる. 図-8で示される結果は, 微視的内部構造の 劣化を損傷パラメー夕等を用いて表す場合には誘導 異方性を扱えるテンソル量として表す必要があるこ とを示唆していて，ファブリックテンソル ${ }^{19}$ などと 合理的に関連づけられることが理想的である.

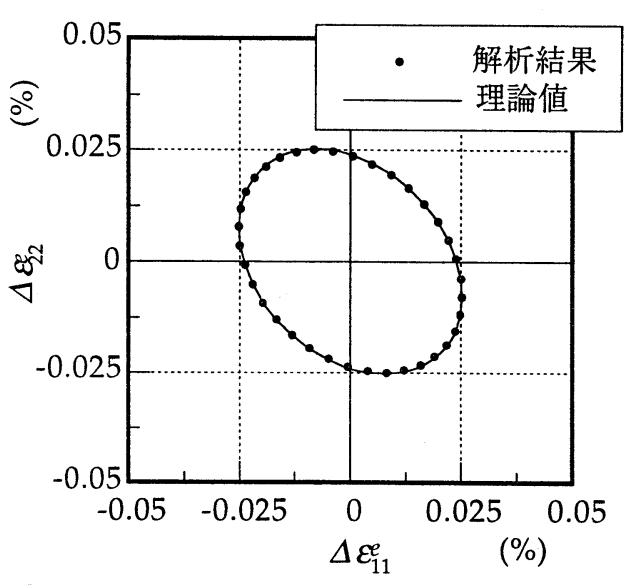

(a) 試験点O（初期状態）

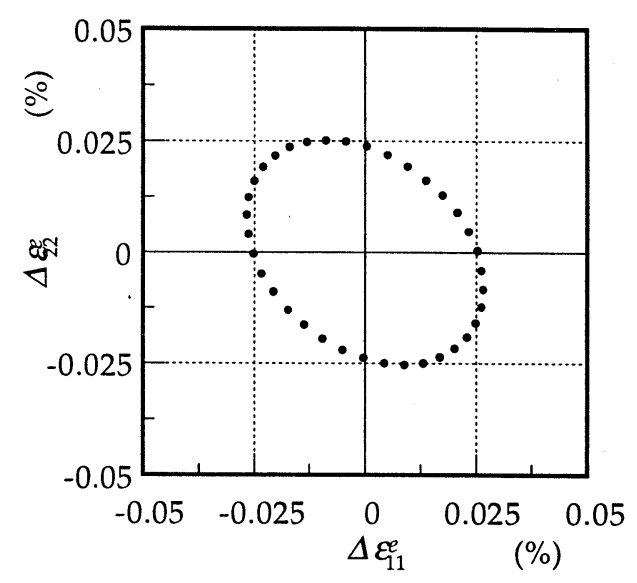

(b) 試験点B（応力比0.2）

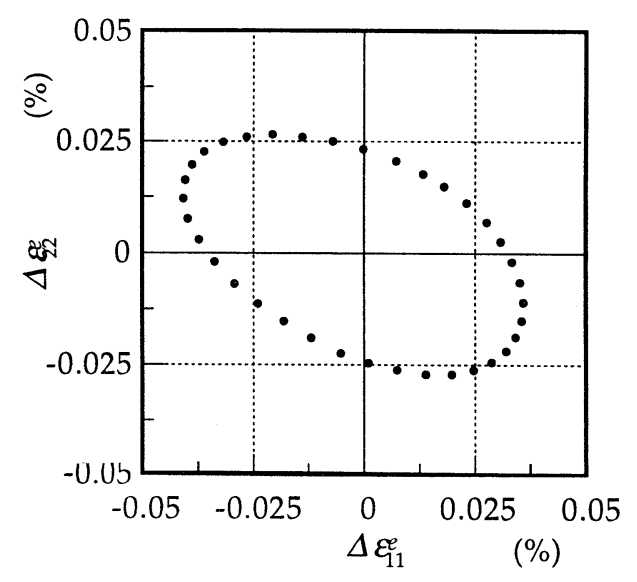

(c) 試験点D（応力比0.4）

図-8 弾性ひずみ増分応答

\section{3 塑性増分応答}

次に, 試験点Cに着目して応カプローブ試験の結 果得られた塑性ひずみ増分の考察を行う。図-9は試 験点Cにおける各応力プローブ方向の塑性ひずみ増 分応答の絶対值 $\left|\Delta \boldsymbol{\varepsilon}^{p}\right|=\sqrt{\Delta \varepsilon_{i j}^{P} \Delta \varepsilon_{i j}^{P}}$ を極座標表示した 主応力空間上にプロットしたものである，同図の角 度は主応力空間におけるプローブ方向の $\sigma_{1}$ 軸（ $x_{1}$ 
軸）からの角度を表す。古典的な流動則に従うとす れば，降伏面の内側に向かう載荷においては塑性ひ ずみ増分は 0 であるので原点上にプロットされる。 また，外側に向かう載荷においては，塑性ひずみ増 分が降伏面の法線方向テンソル $\boldsymbol{n}$ と応力増分テンソ ルの内積に比例して大きくなるので，同図において は完全に円形にプロットされ，その載荷状態での降 伏面の接線は塑性ひずみ増分の絶対值を表す円の接 線となる。図-9より，ここで行った解析の結果得ら れた塑性ひずみ増分の絶対值を連ねた線はほぼ円状 となることがわかり，ほぼ古典的な流動則に従うこ とがわかる.ささらに，その主応力空間上の接線が降 伏面の接線であると推定される，同図にはこの降伏 面の接線とその外向き法線を表す単位のテンソル

（応力空間上ではべクトル） $n$ を示した. 試験点C においては $\boldsymbol{n}$ の方向は主応力空間上の $\sigma_{1}$ 軸から反時 計回りに約 $153^{\circ}$ である。

図-10は試験点Cの各応力プローブ方向の塑性ひず み増分の塑性主ひずみ増分空間上のプロットを示 す。同図に示されている角度は $\Delta \varepsilon_{1}^{p}$ 軸からの角度を 表す。ひずみ空間における各プローブ方向の塑性ひ ずみ増分は応力増分に依らずほぼ一定の方向 $\boldsymbol{m}$ を向 いており，近似的に古典的塑性論における流動則の 仮定が成立すると見なすことも不可能ではない。こ こでの $\boldsymbol{m}$ は塑性主ひずみ空間上で約 $135^{\circ}$ である. なお, 応力テンソルと塑性ひずみ増分テンソルの主 軸の方向は若干異なるがその差は最大で約 $2^{\circ}$ 程度 であるので流動則の検討に関して及ぼす影響はクリ ティカルなものではない. したがって, 平均的な塑 性ひずみ増分の方向を表す単位のテンソル $\boldsymbol{m}$ の主值 を近似的に $m_{1}=m_{11}, m_{2}=m_{22}$ として検討を行う が，この近似による誤差は1\%以下である。

得られた降伏曲線の外向き法線方向 $\boldsymbol{n}$ と平均的塑 性ひずみ増分方向 $\boldsymbol{m}$ とを比較すると明らかに $\boldsymbol{m} \neq \boldsymbol{n}$ であり, 流動則について少なくとも関連流動則が成 立するとみなすことはできず，大局的には非関連流 動則に従うと見なすべきである。ここで行った各応 カプローブ試験点における $\boldsymbol{n}$ と $\boldsymbol{m}$ の方向を図-11に 示す.どのプローブ試験点においても， $\boldsymbol{m \neq n} n$ であ り関連流動則に従うとはみなすことはできない.

しかしながら，非関連流動則を用いる場合図-9に 示した斜線部分では $m_{i j} \Delta \sigma_{i j}<0$ となり, Druckerの安 定性の仮説 ${ }^{20)}$ が満たされない。 そこで, 以下, 試験 点Cにおいて行った応力プローブ試験結果をさらに 詳細に調べ安定条件に関して考察する.

\section{4 安定条件}

図-12はプローブ方向による塑性ひずみ増分方向 の変化を示したものであるが，明らかに塑性ひずみ 増分方向は一定值にはなっていない。ここで, 平均

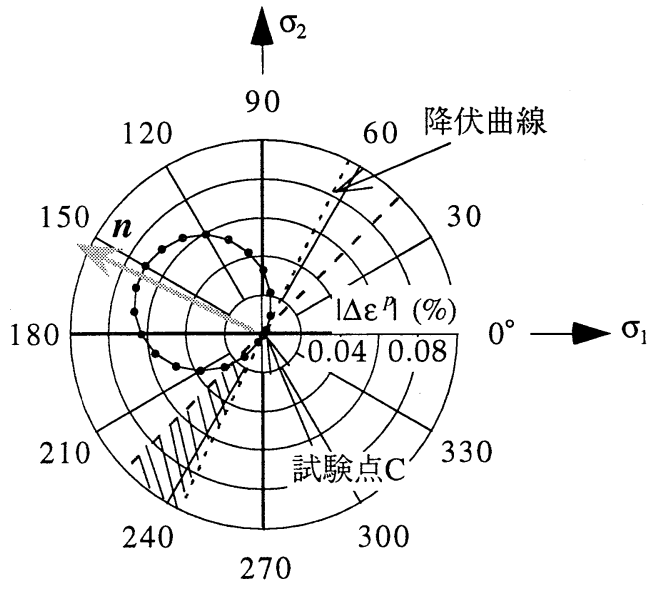

図-9 $\left|\Delta \boldsymbol{\varepsilon}^{p}\right|$ の主応力空間表示（試験点C）

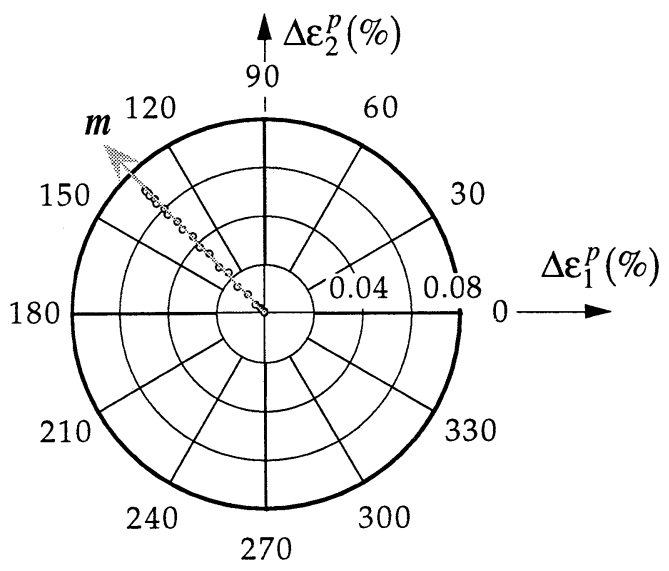

図-10 $\Delta \boldsymbol{\varepsilon}^{p}$ の塑性主ひずみ空間表示（試験点C）

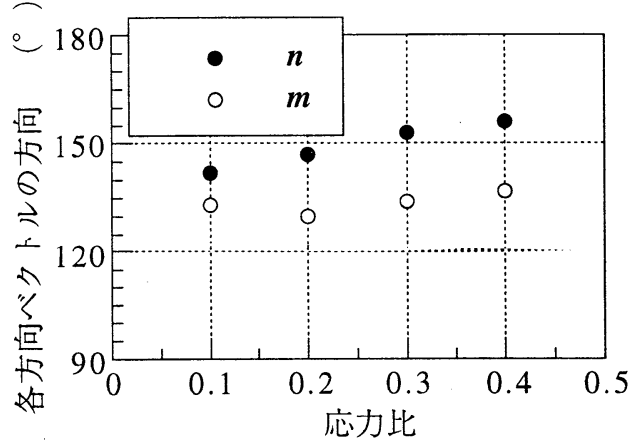

図-11 各プローブ試験点の $\boldsymbol{m}$ と $n$ の方向

的な塑性ひずみ増分方向テンソル $\boldsymbol{m}$ と区別するため に, 各応力増分に対する実際の塑性ひずみ増分の方 向を表す単位のテンソル $\boldsymbol{m}^{*}$ とする. 同図は, 古典 的塑性論における「塑性ひずみ増分方向は応力増分 方向に依らず一定である」といった仮定が粒状体に 対しては完全には成り立たないことを示していて, $\boldsymbol{m}^{*}$ について平均的方向 $\boldsymbol{m}$ からのズレ，いわゆる流 動則の応力増分方向依存性が観察される. 特に, 塑 性ひずみレベルの小さい方向に対して塑性ひずみ増 分方向 $\boldsymbol{m}^{*}$ の平均值 $\boldsymbol{m}$ からのズレが大きく生じてい 


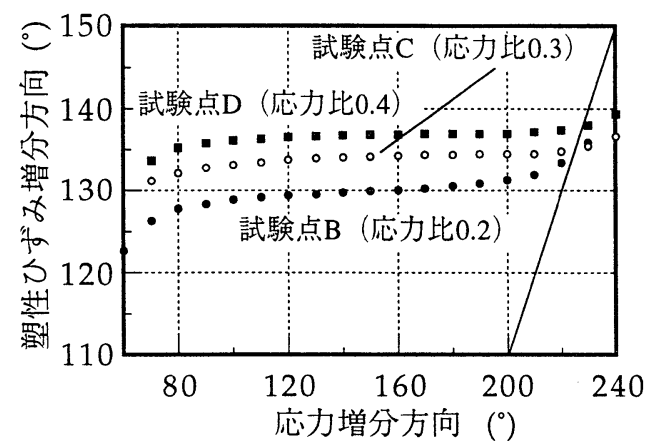

図-12 塑性ひずみ増分の方向

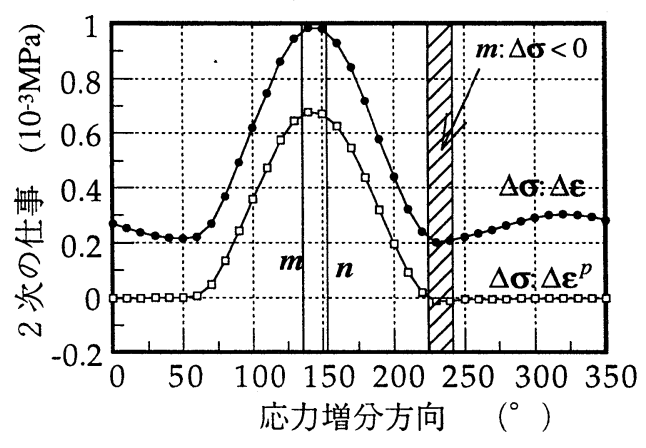

図-13 2 次の仕事増分（試験点C）
ることがわかる．また，平均的塑性ひずみ増分方向 $\boldsymbol{m}$ からのズレは載荷初期ほど大きく, 載荷が進み応 力比が大きくなるほど小さくなる傾向にあることが 確認される. 図中に 2 次の塑性仕事増分が正から負 へ変わる限界線を示した。 もし, 塑性ひずみ増分の 方向 $\boldsymbol{m}^{*}$ が一定值 $\boldsymbol{m}$ で与えられるとすれば，この限 界線より右側では 2 次の塑性仕事増分 $\Delta \sigma_{i j} \Delta \varepsilon_{i j}^{P}$ が負 になりDruckerの安定条件を満たさない.しかし， 解析結果は塑性ひずみ増分方向 $\boldsymbol{m}^{*}$ は一定ではな く, 平均值 $\boldsymbol{m}$ からのズレは 2 次の塑性仕事増分が正 に近づく方向に生じ, その結果として 2 次の仕事増

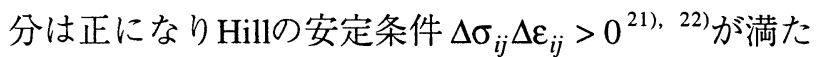
されると考えられる。なおここで行った解析にお いてはどの応力プローブ方向に対しても安定した解 が得られている。

試験点Cにおいて，実際にプローブ方向に対する 塑性仕事増分と仕事増分を算定し図-13に示す。2 次の塑性仕事増分は若干負になる部分もあるが, 仕 事增分は常に正であり, Hillの安定条件は常に満た されている。このように，塑性ひずみ増分方向 $\boldsymbol{m}^{*}$ の平均方向 $\boldsymbol{m}$ からのズレがHillの安定条件を満たす ように生じることは，非常に注目すべきことであ る. 以上の結果は, 粒状体に扔ける塑性ひずみ増分 と応力増分との構成関係が非関連かつ応力増分方向 依存型の流動則を用いるべきことを示唆している。

\section{4. 流動則の応力増分方向依存性}

ここでは，塑性ひずみの応力増分方向依存性が生 じる原因などについて微視的観点から詳細に考察 し，それを表現しうる流動則について検討する。

\section{1 塑性ひずみ増分の偏差成分と体積成分}

まず，応力増分方向による塑性ひずみ増分の偏差 成分と体積成分の変化について検討する。 応力比 0.2, 0.3, 0.4の各試験点において得られた塑性ひずみ 増分を偏差成分と体積成分に分解し, 応力増分方向 との関係を図-14に示す．偏差成分の大きさは降伏
面の単位法線方向 $\boldsymbol{n}$ を中心に常に左右対称となる。 これは, どのような応力状態においても $n_{i j} \Delta \sigma_{i j}$ にほ ほ比例することを示していて，偏差塑性ひずみ増分 の方向は応力増分の方向に依存せずほほ一定にな る.これに対して体積塑性ひずみ増分は $n_{i j} \Delta \sigma_{i j}$ に比 例しないことは明らかであり, 特にプローブ試験点 Cにおいてはその傾向が最も顕著である。

次に，体積塑性ひずみ増分と偏差塑性ひずみ増分 の大きさの比の応力増分方向による変化を図-15に 示す．同図は塑性ひずみ増分の偏差成分と体積成分 の比が応力増分の方向に依存して変化することを示 している．載荷初期には，体積成分の割合が比較的 大きく体積成分の応力増分方向依存性の影響を受け て成分比はその平均值から大きくずれる. 塑性変形 が進むとすべりによる偏差成分が卓越するためより 一定值に近づく。このことは, 塑性ひずみ増分方向 を示した図-12と比較することで良く理解される。

これらの図の比較より応力増分がより圧縮側（角度 小）に与えられる場合には偏差成分に対する体積成 分の大きさが大きくなり, 塑性流動方向も圧縮側に ずれることがわかる．応力増分が引張り側（角度 大）に与えられる場合には体積成分の割合は小さく なり流動方向も引張り側にずれる．以上より，体積 塑性ひずみ増分が $n_{i j} \Delta \sigma_{i j}$ に単純に比例せず, 応力増 分の方向により変化するため, 偏差 ·体積成分の比 が変化し塑性流動方向の応力増分方向依存性として 現れると考えることができる.

古典的な金属塑性論によれば，塑性ひずみ増分と 応力増分との関係は

$$
\Delta \varepsilon_{i j}^{P}=m_{i j} n_{k l} \Delta \sigma_{k l} / h
$$

と書かれて, 塑性ひずみ増分は応力増分の降伏面法 線方向成分 $n_{i j} \Delta \sigma_{i j}$ のみにより生じる. 粒状体の流動 則が古典的塑性論の非関連流動則に従うとした場 合, 体積成分も偏差成分と同様に応力増分の降伏面 法線方向成分 $n_{i j} \Delta \sigma_{i j}$ に比例することになる。また, 各塑性ひずみ増分成分間の比は，応力増分方向によ らず一定となる。しかしながら，図-14,15の結果は 粒状体の流動則が体積成分の応力増分方向依存性に 
より古典的流動則では完全には表現し得ないことを 示している.

本来，古典的塑性論は金属材料を対象として発展 してきた連続体モデルであり，金属材料においては 原子・分子レベルのすべりモードが塑性変形のマイ クロメカニズムであるとされている。ささらに，その ような塑性変形には塑性体積変化は伴わないと仮定 され，一般には関連流動則が用いられる。一方, 砂 などの粒状体は粒子間のすべりによるせん断変形に 伴いダイレイタンシーが生じることが知られてい る。ここでの解析結果に依れば，粒状体においても 塑性ひずみ増分の偏差成分として現れるような粒子 間のすべりに直接的に起因する塑性変形に関して は, 塑性流動方向が応力増分方向に依存せずほぼ一 定となり流動則が成立する.しかしながら，せん断 に伴う体積变化は，応力増分の方向に大きく依存す るため, 塑性体積変化を重視しなくても良い金属材 料を対象としてきた古典的塑性論では粒状体の塑性 挙動を精緻には表現し得ないと考えられる。

\section{2 接線塑性ひずみの導入}

ここで, 塑性ひずみ増分の応力増分方向依存性を 表現するために, 式(16)で表される応力堌分の降伏 面法線方向成分により生じる塑性ひずみ項に加え, 降伏面接線方向成分による項 $\Delta \boldsymbol{\varepsilon}^{p T}$ を導入する.

$$
\Delta \varepsilon_{i j}^{p}=\Delta \varepsilon_{i j}^{p N}+\Delta \varepsilon_{i j}^{p T}=m_{i j} n_{k l} \Delta \sigma_{k l} / h+\Delta \varepsilon_{i j}^{p T}
$$
ここで, $\Delta \boldsymbol{\varepsilon}^{p T}$ を生じさせる応力増分の接線方向成 分 $\Delta \boldsymbol{\sigma}^{T}$ を次式のように定め, 接線応力増分と呼ぶ.

$$
\Delta \sigma_{i j}^{T}=\Delta \sigma_{i j}-\Delta \sigma_{i j}^{N}=\Delta \sigma_{k l} t_{k l} t_{i j}
$$

このような応力増分の分解の概念を図-17に示す.

ここで, $t$ は応力増分の降伏面接線方向成分の方向 を表す単位のテンソルで 2 次元の場合には図-16に 示したように 2 ついないが，3 次元問題において は降伏面接平面内の任意の単位のテンソルとなる. また， $\Delta \boldsymbol{\sigma}^{N}$ は応力増分の降伏面法線方向成分であ り,これを法線応力増分と呼び次式のように表す。

$$
\Delta \sigma_{i j}^{N}=\Delta \sigma_{k l} n_{k l} n_{i j}
$$

このような, 接線塑性ひずみ增分の概念はRudnicki とRice ${ }^{3)}$ により提案された概念である。Rudnickiと Riceはダイレイタンシーを伴う地盤材料の変形局所 化解析のために, $J_{2}$ 流動則を拡張し接線応力増分に よる接線ひずみ増分項を付加することを提案した。

しかし, 弾塑性構成則にいきなり付加したため適用 範囲が比例負荷近傍に限定される。橋口齐は接線ひ ずみ増分を下負荷面モデルに取り入れて，ひずみ増 分の連続性条件を満たす等, RudnickiとRiceの欠点 を補う合理的な構成則を定めている。

接線応力増分による塑性ひずみ増分は 2 つの塑性 ひずみ成分の比の一定值からのずれを生じさせるも のであると考えることができる，塑性ひずみ増分の

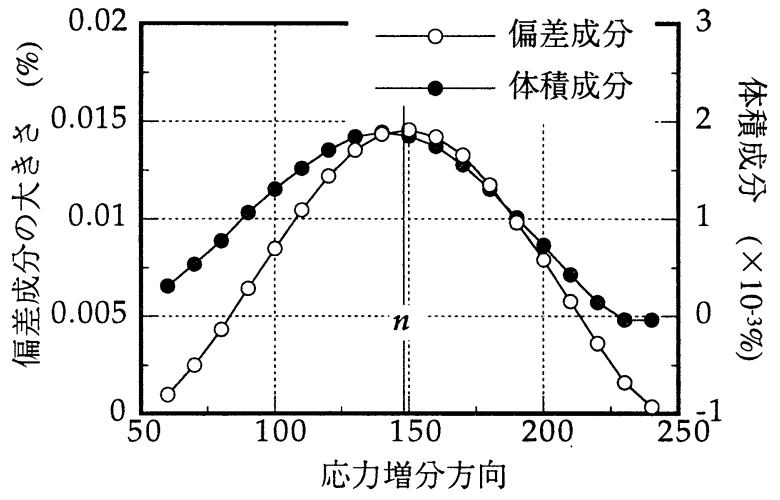

(a) 試験点B（応力比0.2）

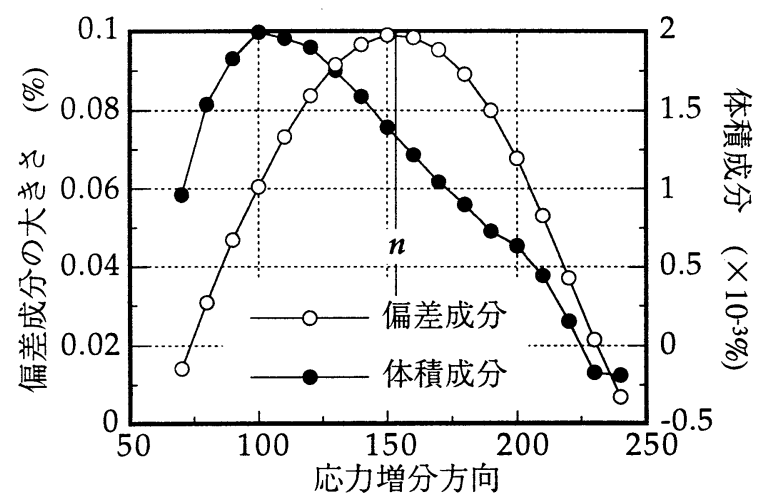

(b) 試験点C（応力比0.3）

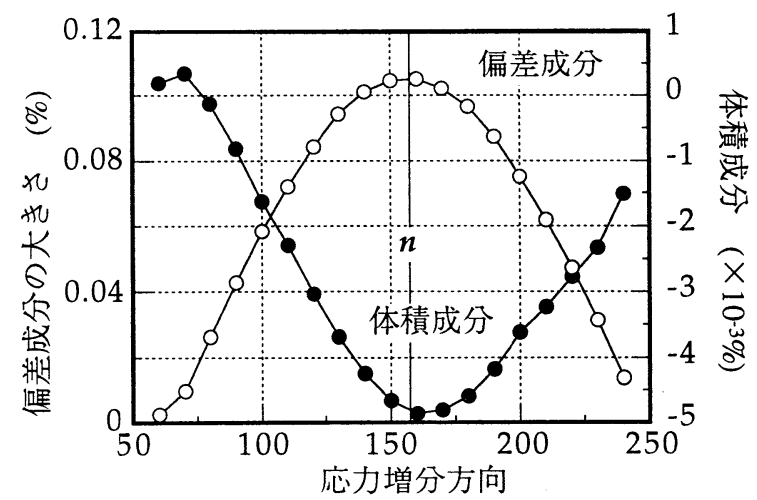

(c) 試験点 $\mathrm{D}$ (応力比0.4)

図-14 塑性ひずみ増分の偏差成分と体積成分

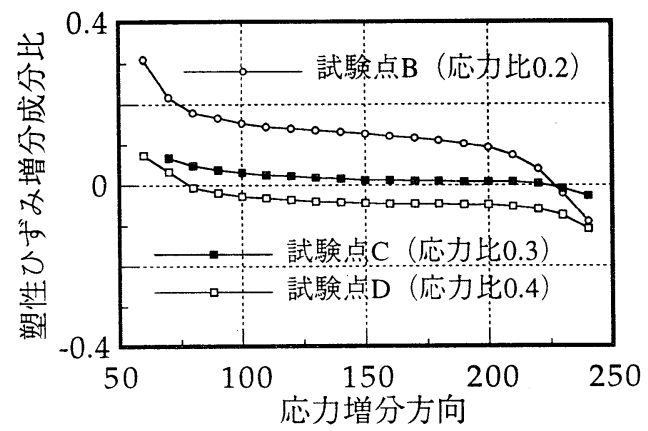

図-15 塑性ひずみ増分の偏差成分と体積成分の比 
偏差成分は法線応力増分に比例的であるので， $\Delta \boldsymbol{\varepsilon}^{p T}$ は主に体積成分，つまりダイレイタンシー現象に影 響を与える。粒状体の微視構造は非均質性が強く応 力増分の法線成分のみにより非可逆性の微視構造変 化が生じると考えるよりも，接線成分を含めた全応 力増分により生じるとすることは物理的にも自然な 考え方であるように思われる。

上述の応力プローブ試験結果より，接線塑性ひず み増分 $\Delta \varepsilon_{i j}^{T}$ は接線応力増分の方向に生じるので次 式のように表しておく。

$$
\Delta \varepsilon_{i j}^{T}=\beta \Delta \sigma_{i j}^{T}=\beta\left(\delta_{i k} \delta_{j l}-n_{i j} n_{k l}\right) \Delta \sigma_{k l} \quad(\beta \geq 0)
$$

古典的な金属塑性論においては，流動則は関連 · 非関連を問わず流動則は塑性ポテンシャル面に垂直 で応力増分方向に依存しないという仮定を設けてい る.しかし，前述したように粒状要素解析において は流動方向の応力増分方向依存性が観察される。変 形局所化による塑性不安定現象などの解析や地盤材 料などの塑性変形が圧力に依存する材料の塑性体積 変化をより精緻に表現する場合には，流動則の応力 増分方向依存性の取り扱いが不可欠である。以下， 式(17)のような接線塑性ひずみ増分項を付加した流 動則を拡張流動則と呼ぶ.

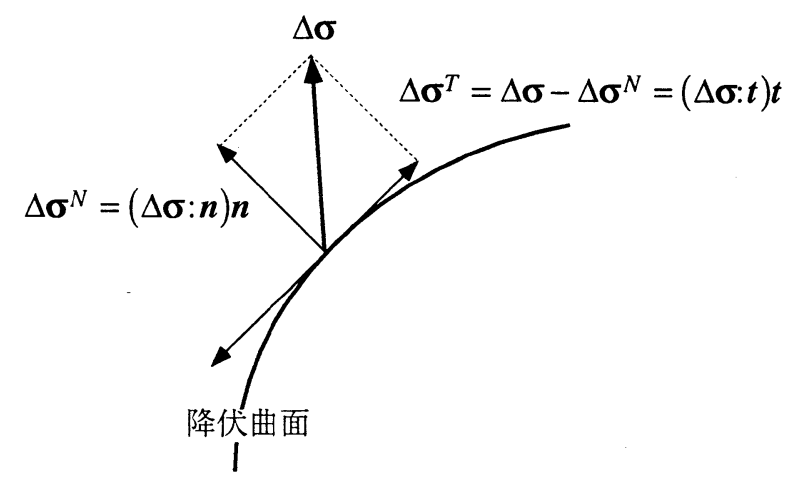

図-16 接線応力増分の概念

\section{3 散逸エネルギーと変形の分解の概念}

粒状体の微視的なエネルギー散逸機構は, 粒子間 の摩擦によるものが主体的であるが，すべりを伴う 非可逆的な構造变化により初期の応力状態まで除荷 した際に回復しない粒子間の弾性エネルギーの存在 が指摘されている ${ }^{27)}$ 。このことは 6 個の球粒子を用

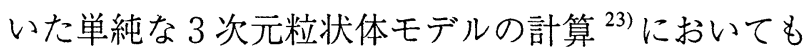
指摘されていて，このようなエネルギーが粒状体の 硬化に大きく関わっていることが示されている。こ れは, すべりに伴って粒状体内部の粒子構造变化が 非可逆性であるために局所的な接触力が粒子間に残 留することにより生じるためと考えることができ る。このような非可逆性の構造変化に起因して残留
した接触力によるエネルギーは従来粒状体力学で考 慮されていないエネルギー量であり，以下これを残 留エネルギーと称することとする．粒状体のせん断 変形に伴う散逸エネルギーは粒子間のすべりによる 摩擦エネルギーのみではなく, 非可逆性の構造変化 に起因する残留エネルギーも含まれる。ここではま ず，すべり摩擦と微視構造変化といった二つの異な る散逸機構により生じるエネルギー量に着目し, 微 視的現象と巨視的に現れる流動則の応力増分方向依 存性との関係について考察する。

図-17に各プローブ方向に対する残留エネルギー 増分と摩擦エネルギー増分との比を示す。同図は単 位の摩擦エネルギー増分に対する残留エネルギー増 分が応力増分方向に依存して変化することを表して いる．同図と図-15を比較すると巨視的に現れる塑 性ひずみ増分比の応力増分方向依存性が粒子間接触 点の 2 つの非可逆性のエネルギー増分の比と密接に 関連していることがわかる，応力増分の方向がより 圧縮側である場合には，単位の摩擦エネルギーに対 して非可逆性微視構造変化が大きい. そして，巨視 的にはより大きな体積変化として現れる，応力増分 方向がより引張り側に与えられると摩擦エネルギー が卓越し，巨視的に塑性体積ひずみ成分が小さく現 れる。.また, 応力比 0.2 の場合には 0.3 の場合と比較 して散逸エネルギー増分比の平均からのずれが大き く, この場合には流動方向の平均值からのずれもよ り大きく現れている。したがって，応力増分方向に 依存して摩擦によるエネルギー散逸とそれに伴う微 視構造変化によるエネルギー散逸の大きさの割合が 変化することで, 塑性ひずみ流動則の応力増分方向 依存性がもたらされると考えることができる。

以上の塑性ひずみと散逸エネルギーに関する考察 を基に粒状体の塑性変形を分解し，エネルギー，応 力増分成分の関係をまとめて図-18に示す.まず, 粒状体においてエネルギー散逸をもたらす微視的現 象は粒子間のすべりとそれに伴う非可逆性の微視構 造変化であり，エネルギー的にはすべり摩擦は摩擦 エネルギー, 非可逆性微視構造変化は残留エネル ギーとして現れる，また，粒子間のすべりは法線応

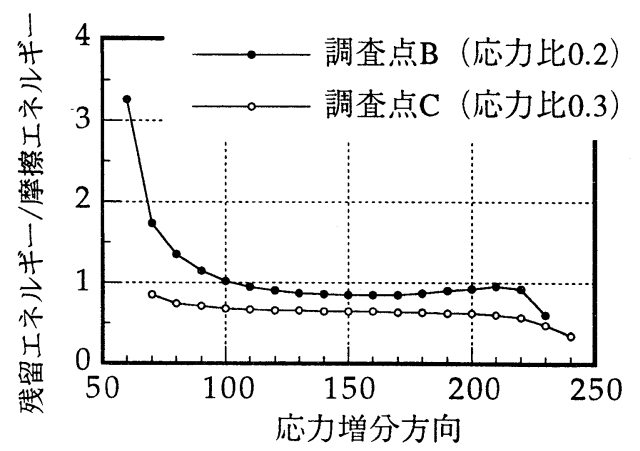

図-17 残留エネルギーと摩擦エネルギーの比 


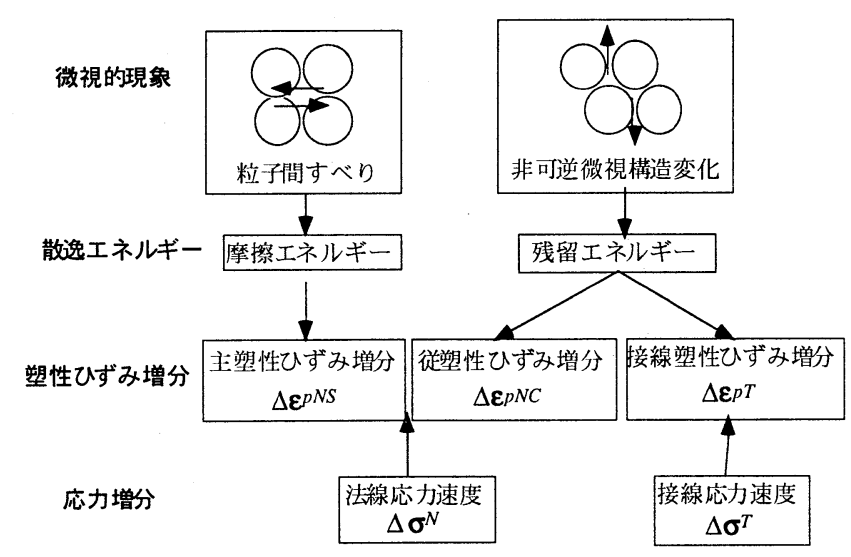

図-18 変形の分解の概念

力増分のみにより発生し, 微視構造変化は全応力増 分により発生すると考える。すべり摩擦により直接 的に生じるひずみ成分を主塑性ひずみ増分 $\Delta \boldsymbol{\varepsilon}^{p N S}$ と すれば， $\Delta \boldsymbol{\varepsilon}^{p N S}$ は法線応力増分のみと関係づけられ る。残留エネルギーにより生じる塑性ひずみ成分は 法線応力増分による従塑性ひずみ増分 $\Delta \varepsilon^{p N C}$ と接線 応力増分による接線塑性ひずみ増分 $\Delta \varepsilon^{p T}$ とに分解 して考える。 $\Delta \boldsymbol{\varepsilon}^{p N C}$ はすべりに拘束を与え，主塑性 ひずみ増分 $\Delta \boldsymbol{\varepsilon}^{p N S}$ に拘束を与えると考えることがで きる．金属材料がほぼ関連流動則に従うのに対して 粒状体において非関連になるのは，この拘束による ものと考えられる．接線応力増分により生じる部分 $\Delta \boldsymbol{\varepsilon}^{p T}$ は主塑性ひずみ増分に従属して生じるがそれ に拘束を与えない，粒状体の構成則を合理的に定め るためには，このような変形の分解を念頭におく必 要があるが，ここでは，拡張流動則を用いて接線塑 性ひずみ増分を付加した影響について検証する。

\section{4 拡張流動則の検証}

拡張流動則は式(17)と(20)をまとめて次式のよう に書かれる.

$$
\Delta \varepsilon_{i j}^{p}=\frac{1}{h} m_{i j} n_{k l} \Delta \sigma_{k l}+\beta\left(\delta_{i k} \delta_{j l}-n_{i j} n_{k l}\right) \Delta \sigma_{k l}
$$

乃はここでは簡単のためスカラー係数とするが, 粒 状要素解析の結果を考慮し接線塑性ひずみ速度 $\Delta \boldsymbol{\varepsilon}^{p T}$ がDruckerの安定条件を満足する方向に生じる と考えて, Druckerの安定条件を満たし接線塑性ひ ずみ増分項の寄与率が最小（ $\beta$ が最小）になるよう な $\beta$ 用いて拡張流動則を検証する。この $\beta$ は,

$$
\beta=\frac{1-\left(m_{k l} n_{k l}\right)^{2}}{4 m_{k l} n_{k l} h}
$$

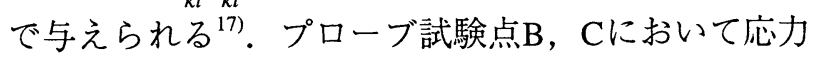
プローブ試験を行い, 塑性ひずみ増分応答を粒状要 素解析と比較する。試験点 $\mathrm{B}, \mathrm{C}$ の応力比はそれぞ れ0.2，0.3である。

図-19は各応力プローブ方向に対する主塑性ひず

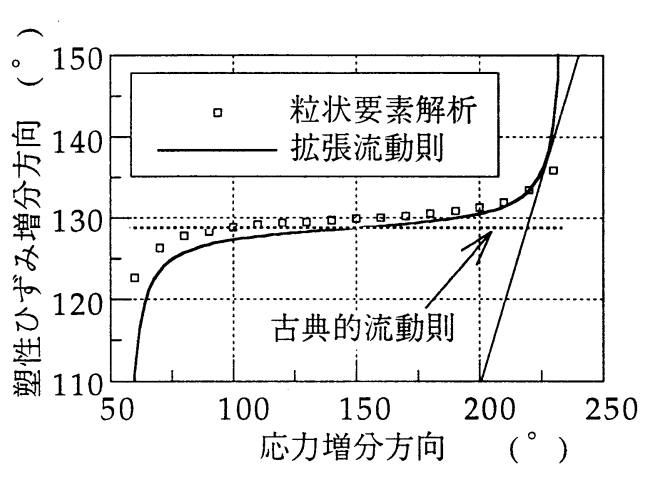

(a) プローブ試験点B

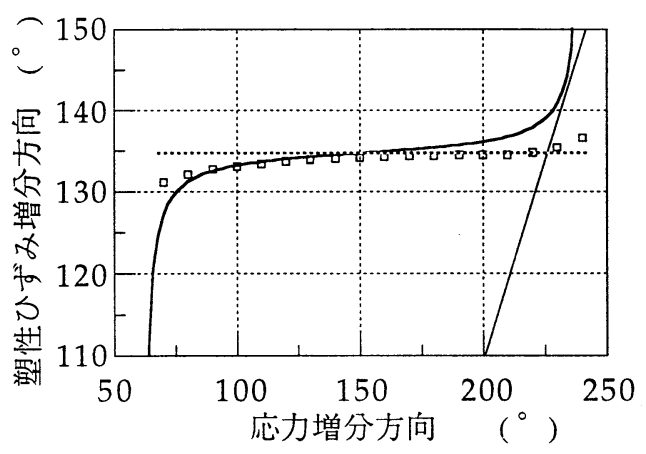

(b) プローブ試験点C

図-19 变形の分解の概念

み増分空間における塑性ひずみ増分方向を示したも のである.Druckerの安定条件を満たす限界線を斜 線で示し，これより右側では安定条件を満たさな い.また，同時に古典的流動則の塑性ひずみ増分の 方向を破線で示す. 塑性ひずみ増分の方向は主塑性 ひずみ増分空間の 1 軸方向から反時計回りの角度で 示した。図-19より拡張流動則を用いることで応力 増分の方向により流動方向が変化する接線塑性ひず みの影響が顕著に現れていて，接線塑性ひずみの効 果により応力増分方向に依存した流動方向の変化を 良くシミュレートできている，さらに，常にDrucker の安定条件を満たしていることがわかるが，これを 満たす条件のみによって設定した係数队により, 実 際の粒状要素解析の結果に比べて極端な流動方向の ずれが生じる。粒状要素解析の結果によれば, 比較 的載荷初期において塑性ひずみ増分方向の平均方向 からのずれが顕著に現れていて, 応力のピークに近 づくほどそのずれが小さくなることが観察される. このため載荷が進むほど不安定なプローブ方向が増 加すると考えることができるが，ここで用いた拡張 流動則においては常にDruckerの条件を満たすよう に接線塑性ひずみが生じると仮定しているので, 履 歴に依存して接線塑性ひずみ項の影響が変化するこ とはない。粒状要素解析結果とより適合する流動則 を定めるためには，係数及の設定に関する履歴に依 存した修正が必要であるように思われる。 


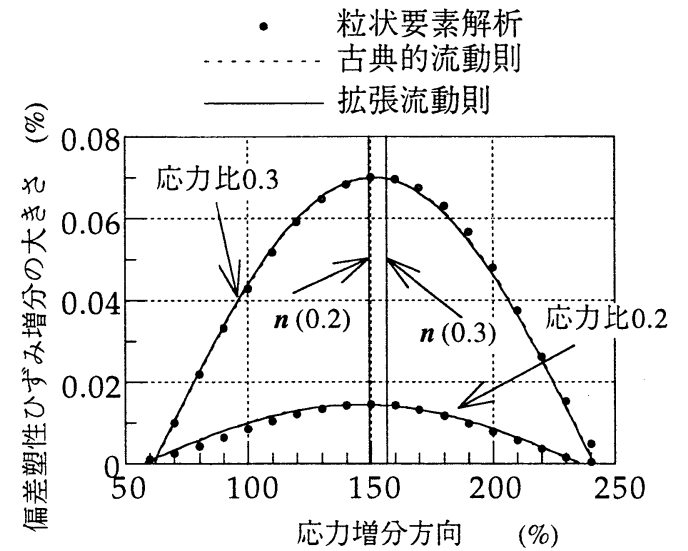

図-20 塑性ひずみ増分の偏差成分の検証

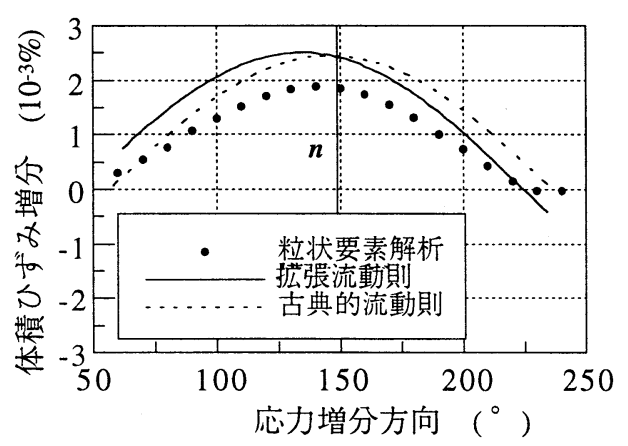

(a) プローブ試験点B

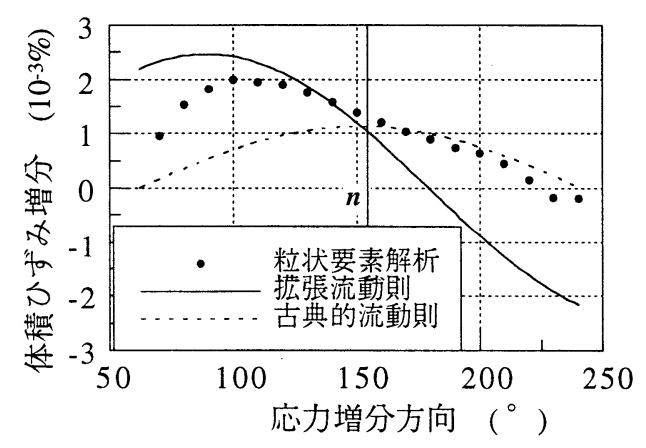

(b) プローブ試験点C

図-21 塑性ひずみ増分の体積成分の検証

次に，接線塑性ひずみ増分項を付加したことによ る塑性ひずみ増分の各成分の応答の差異について考 察する。粒状要素解析の結果と拡張流動則による計 算結果を偏差塑性ひずみ増分, 体積塑性ひずみ増分 に関して比較する。比較のため古典的流動則の計算 結果も同時に示す.

図-20は偏差塑性ひずみ増分について比較した図 であるが，塑性ひずみ増分の偏差成分には接線塑性 ひずみ増分の影響はほとんど表れず, 粒状要素解析 の結果とほぼ等しい応答を与え, それは法線応力増 分に比例する。古典的流動則もほぼ等しい計算結果 である。体積塑性ひずみ増分の比較を図-21に示す が, 古典的流動則の体積成分が偏差成分と同様に法

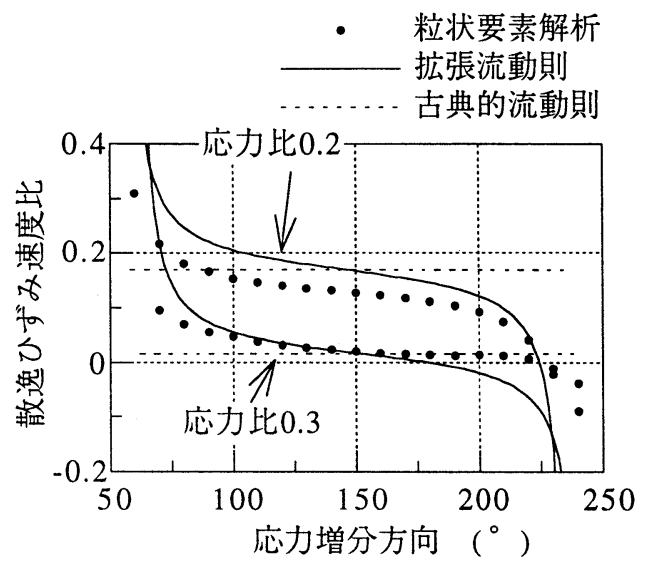

図-22 塑性ひずみ増分の成分の比の検証

線応力増分に比例するのに対して, 拡張流動則の場 合には粒状要素解析結果と合致した結果となる。応 力比が増加するのに従い接線応力増分の影響が大き くなり，体積塑性ひずみ増分の極大点が降伏面法線 方向からずれていくような結果も接線応力増分によ り生じる接線塑性ひずみ項を付加することで表現さ れる。ただ，ここで設定した係数乃においては流 動方向のずれと同様にその傾向を極端に表現するこ とになる。

図-22に塑性ひずみ増分の体積成分と偏差成分の 比を応力増分方向により比較した，接線塑性ひずみ 項を考慮することで応力増分により塑性ひずみ増分 比が変化する応答を再現可能となる. 法線応力増分 のみを考慮した古典的流動則においてはこのような 塑性ひずみ増分比の応力増分方向依存性は表現でき ず，特に体積塑性ひずみに与える影響が強いためダ イレイタンシーに関する精密な結果を必要とする場 合には接線塑性ひずみ項を付加することが有効な方 法であると考えられる。

以上より，塑性ひずみを通常の法線応力増分によ り生じる摩擦則に基づく塑性ひずみに加えて, 残留 エネルギーの一部を想定した接線塑性ひずみを考慮 することにより，粒状体の応力増分方向依存型の流 動則を良く表現することができる。さらに，応力増 分方向依存型流動則を用いることにより粒状要素解 析により得られる流動方向をより精密に表現可能で あることが示された。したがって，ここで示した拡 張流動則は，その傾向を過大に表現してしまうとは いえ, 非古典的流動則の一つの基準の形式となり得 るといえよう。たたし，係数 や物理的意味づけが課題として残される。

\section{5. おわりに}

本研究においては, 周期境界制御GEMを用いて 応力プローブ試験シミュレーションを行い, 従来の 
境界粒子を配したGEMによる一連の解析結果を再 確認すると共に, 粒状体の流動則の応力増分方向依 存性について詳細に考察した。

特に, 塑性ひずみ増分の体積成分が応力増分方向 に強く依存するため, 流動則の応力増分方向依存性 が現れることがわかった。さらに，それは微視的内 部構造変化に起因して生じることなどを考察し, 塑 性変形を合理的に分解し, 各成分を微視的なエネル ギー散逸機構と結びつけることができた.

また，流動則の応力増分方向依存性を表現するた めに接線応力増分により生じる接線散逸ひずみ増分 項を付加した拡張流動則を導入し, 粒状要素解析と 古典的流動則との比較を通して, 応力増分方向依存 性を表現する上で非常に有効であることを示した。

本研究で行った解析は, 弾性円形粒子を用いた理 想的な粒状体モデルによるものであるが，粒状体の 接触・摩擦といった離散性・非均質性から生じる性 質を十分反映している. 砂などの実際の材料の変形 は粒子破砕などを含むより複雑なものであるが，こ こで得られた粒状体の巨視的な構成モデルに関する 種々の知見は, 粒子性といった粒状体最大の特徵を 反映したものであると考えられる.

\section{参考文献}

1) $\mathrm{Wu}, \mathrm{W}$. and Niemunis, A.: Beyond Failure in Granular Materials, International Journal fot Numerial and Analytical Methods in Geomechanics, Vol. 21, pp. 153-174, 1997.

2) Herle, I. and Gudehus, G.: Determination of Parameters of a Hypoplastic Constitutive Model from Properties of Grain Assemblies, Mechanics of Cohesive-Frictional Materials, Vol. 4, pp. 461-486, 1999.

3) Rudnicki, J. W. and Rice, J. R.: Conditions for localization of deformation in pressure-sensitive dilatant materials, J. Mech. Phys. Solids, Vol. 23, pp. 371-394, 1975.

4) Hashiguchi, K.: Fundamental requirements and formulation of elastoplastic constitutive equations with tangential plasticity, Int. J. Plasticity, Vol. 9, pp. 525-549, 1993.

5) Anandarajah, A., Sobhan, K. and Kuganethira, N.: Incremental Stress-Strain Behavior of Granular Soil, Journal of Geothechnical Engineering, ASCE, Vol. 121, pp. 57-67, 1995.

6) Royis, P. and Doanh, T.: Theoretical Analysis of Strain Response Envelopes Using Incrementally Nonlinear Constitutive Equations, Int. J. Numerical and Analytical Methods in Geomechanics, Vol. 22, pp. 97-132, 1998.
7) 武 建勲, 岸野佑次, 京谷孝史 : 2次元モデルプ ローブ試験による弾塑性挙動の考察, 構造工学 論文集, JSCE, Vol. 44A, pp. 399-408, 1998.

8) 武 建勲, 岸野佑次, 浅沼秀雄: マイクロメカニ ズムによる粒状体の流動則の考察, 応用力学論 文集, JSCE, Vol. 1, pp. 497-506, 1998.

9) 岸野佑次, 武 建勳：Hillの安定条件の粒状体 への適用性について, 土木学会論文集, No. 631/III-48, pp. 83-95, 1999.

10）金子賢治, 岸野佑次, 林 直宏, 京谷孝史 : 粒状 要素解析による地盤材料損傷モデルの定式化, 応用力学論文集, JSCE, Vol. 2, pp. 427-438, 1999.

11）金子賢治, 寺田賢二郎, 京谷孝史, 岸野佑次 : 非 線形均質化理論に基づく粒状体マルチスケール 解析法の開発とその応用, 土木学会論文集, 2001, 6. (揭載予定)

12) Cundall, P. A. and Strack, O. D. L.: A Discrete Numerical Model for Granular Assemblies, Géotechnique, Vol. 29, pp. 47-65, 1979.

13) Kuhn, M. R.: Structured Deformation in Granular Materials, Mechanics of Materials, Vol. 31, pp. 407429, 1999.

14) Jensen, R. P., Bosscher, P. J., Plesha, M. E. and Edil, T. B.: DEM Simulation of Granular Media -Structure Interface: Effects of Surface Roughness and Particle Shape, Int. J. Numerical and Analytical Method of Geomechanics, Vol. 23, pp. 531-547, 1999.

15) Lanier, J., Jean, M.: Experiments and Numerical Simulations with 2D Disks Assembly, Powder Technology, Vol. 109, pp. 206-221, 2000.

16）岸野佑次：新しいシミュレーション法を用いた 粒状体の準静的挙動の解析, 土木学会論文集, No. 406/III-11, pp. 97-116, 1989.

17）金子賢治：ミクロとマクロを結合した粒状体解 析モデルの構成に関する研究, 東北大学博士学 位論文, 2001 .

18）武 建勳：粒状体の微視力学的研究, 東北大学 博士論文, 1998 .

19) 土質工学会: 粒状体の力学, 土質工学会, 1993.

20) Drucker, D. C. and Ming, L.: Triaxial Test Instability of A Nonassociated Flow-Rule Model, Journal of Engineering Mechanics, ASCE, Vol. 119, pp. 11881204, 1993.

21) Hill, R.: On Uniquness and Stability in The Teory of Finite Elastic Strain, J. Mech. Phys. Solids, Vol. 5, pp. 229-241, 1957.

22) Hill, R.: A General Theory of Uniquness and Stability, J. Mech. Phys. Solids, Vol. 6, pp. 236-249, 1958.

23）金子賢治, 岸野佑次, 京谷孝史：微視力学に基づ く粒状体の構成則の定式化, 応用力学論文集, JSCE, Vol. 1, pp. 469-480, 1998.

（2001 年 4 月 20 日 受付） 